\title{
Detection of Ki-ras gene point mutations in bile specimens for the differential diagnosis of malignant and benign biliary strictures
}

\author{
J-C Saurin, M-O Joly-Pharaboz, P Pernas, L Henry, T Ponchon, J-J Madjar
}

\begin{abstract}
Background and aim-The present study was undertaken to determine if detection of Ki-ras gene point mutations in bile specimens could differentiate between benign and malignant biliary strictures. Patients-Bile specimens were obtained from 117 patients exhibiting a stricture of the main bile duct, the nature of which was assessed by cholangiography, histology, and follow up.

Methods-DNA from frozen bile specimens was extracted, amplified, and tested for codon 12 point mutations of Ki-ras gene using sequence specific oligonucleotide hybridisation and mutant allele specific amplification.

Results-DNA amplification was successful in 110/117 bile specimens (94\%). Detection of Ki-ras gene mutations in bile specimens was positive in $24.4 \%$ (22/90) of patients with malignant strictures, in $31.4 \%(22 / 70)$ when only primary malignant tumours were considered, and in $4 \%$ $(1 / 25)$ of patients with benign strictures. Of the 49 patients with histological specimens obtained before surgery, the sensitivity of histology, Ki-ras mutation analysis, and combined methods was $59.2 \%, 28.6 \%$, and $73.5 \%$ respectively.

Conclusions-Our study showed that Ki-ras mutations may be detected in about one third of bile specimens from patients with primary tumours invading the main bile duct. Detection of such mutations appears to be specific and may help to differentiate between benign and malignant biliary strictures.

(Gut 2000;47:357-361)
\end{abstract}

Keywords: biliary strictures; bile specimens; Ki-ras gene mutations

Determining the cause of a stricture of the main bile duct, either benign or malignant in nature, is a prerequisite for treatment. The diagnosis of malignant biliary strictures rests on the identification of tumour cells obtained using various methods. Percutaneous fine needle aspiration requires the presence of a tumour mass: however, this can be visualised by ultrasonography or computer assisted tomography (CT) in only $40 \%$ of hilar cholangiocarcinomas. ${ }^{1}$ Cytology performed directly on bile allows detection of malignant cells in only $6-26 \%$ of cancer cases. ${ }^{23}$ Cytology after endobiliary brushing, and histology on biopsies, give somewhat better results with a higher sensitivity in cases of pancreatic tumours compared with cholangiocarcinomas. ${ }^{4}$ However, although endobiliary brushing can be performed in up to $90 \%$ of biliary strictures, biopsies can be obtained in only $61 \%$ of cases. $^{5-8}$ These two methods allowed us to detect malignant cells in $35 \%$ and $43 \%$ of malignant biliary strictures, respectively, in a large prospective study. ${ }^{6}$ The use of serum markers of malignancy is of little help. Ca 19-9 is not specific for malignancy in associated cholangitis, ${ }^{910}$ and serum anti-p53 antibodies are detectable in only $5 \%$ of cholangiocarcinomas. ${ }^{11}$ Therefore, new methods, such as molecular biology and image cytometry, ${ }^{12}$ are required to improve the differential diagnosis of benign and malignant biliary strictures before surgery.

Mutations of the Ki-ras oncogene have been described in several human carcinomas, including pancreas and bile duct cancers. ${ }^{13} 14$ These point mutations appear to be of biological significance in the complex process of cell transformation. ${ }^{15}$ Therefore, when detected, they provide additional information on malignancy. Such point mutations mainly reside in the first two nucleotides of codon 12, making their detection by polymerase chain reaction (PCR) feasible. In carcinomas of the pancreas visualised at ultrasonography, Ki-ras gene mutations were detected in $64 \%$ of the specimens obtained by fine needle aspiration, with no false positive results. ${ }^{16}$ Amplification of DNA from bile specimens is also possible, revealing point mutations associated with malignant strictures of the main bile duct. ${ }^{17}{ }^{18}$ However, the usefulness of detecting Ki-ras mutations has not yet been evaluated in a large prospective series of patients with benign and malignant biliary strictures.

We have assessed the value of detecting codon 12 point mutations of the Ki-ras gene in DNA extracted from bile specimens for the differential diagnosis of malignant and benign biliary strictures.

\section{Materials and methods}

PATIENTS

Patients were referred to Edouard-Herriot Hospital, a tertiary care unit for endoscopy and

Abbreviations used in this paper: MASA, mutant allele specific amplification; PCR, polymerase chain reaction; SDS, sodium dodecyl sulphate; $\mathrm{SSOH}$, sequence specific oligonucleotide hybridisation; SSC, standard saline citrate; UTP, uridine 5'-triphosphate; TTP, thymidine 5'-triphosphate; CT, computed tomography. 
radiology, for treatment of malignant or benign extrahepatic biliary strictures. Prospectively, 117 unselected patients were included in the study, between March 1994 and January 1997.

FINAL DIAGNOSIS

Diagnostic methods

The nature of the biliary strictures was assessed by a combination of the following methods: (i) radiological imaging including ultrasonography, CT scan, and cholangiography; (ii) cytology or histology on specimens obtained by endoscopic brushing or biopsies and, when possible, by percutaneous fine needle aspiration, depending on the morphology of the strictures and the presence and localisation of a tumour mass; (iii) surgery; and (iv) medical history and follow up.

\section{Malignant strictures}

Patients with suspected malignant strictures were divided into three groups. Group 1 included patients in whom the diagnosis of malignancy was considered certain. Carcinoma was proved at histology on specimens obtained at surgery or by non-surgical techniques. Group 2 included patients with a suspected diagnosis of malignancy; histological diagnosis was not available but other data obtained by cholangiography or other imaging systems were in keeping with a diagnosis of malignancy, which was confirmed by medical follow up showing progressive deterioration of the patient's general status leading to death. Group 3 consisted of patients who were excluded from the final analysis for different reasons. For them, cholangiography and other imaging methods indicated malignant strictures but histological samples were not available. Moreover, their general status was either unchanged or altered but they were still alive or lost at follow up by the end of the study.

\section{Benign strictures}

The stricture was considered benign when data obtained by cholangiography and other imaging methods suggested a diagnosis of benign stricture, and when the patient's general status was preserved.

BILE SAMPLES AND DNA EXTRACTION

Fresh bile $(1 \mathrm{ml})$ was collected in tubes at the time of drainage and immediately frozen in liquid nitrogen. For DNA extraction, $0.5 \mathrm{ml}$ of lysis buffer (0.5 M Tris HCl, pH 9.0, $16 \mathrm{mM}$ EDTA, $10 \mathrm{mM} \mathrm{NaCl}$ containing $0.5 \%$ sodium dodecyl sulphate (SDS), and $0.1 \mathrm{mg} / \mathrm{ml}$ of proteinase $\mathrm{K}$ ) was added to the bile sample and incubated overnight at $50^{\circ} \mathrm{C}$. DNA was purified by two successive extractions, first by addition of phenol-chloroform-isoamyl alcohol $(25: 24: 1)$ and second by addition of chloroform-isoamyl alcohol (24:1). DNA was then precipitated by adding three volumes of ethanol in the presence of $0.1 \mathrm{M} \mathrm{CH}_{3} \mathrm{COONa}$.

DNA AMPLIFICATION

PCR followed by PCR-mutant allele specific amplification (PCR-MASA) were performed with primers identical to those described previously. ${ }^{19}$ The first PCR allows amplification of the sequence of $\mathrm{Ki}$-ras gene coding for the first exon. To avoid false positive reactions by amplification of previous PCR products, deoxyuridine 5'-triphosphate (dUTP) was used instead of deoxythymidine 5'triphosphate (dTTP), leading to new PCR products containing dU. The first PCR was performed in $1 \times$ PCR buffer (Eurobio, Les Ulis, France) with 10-100 ng of target DNA, 2 $\mathrm{mM} \mathrm{MgCl} 2,180 \mu \mathrm{M}$ of each dNTP, $0.8 \mu \mathrm{M}$ of each primer, $1 \mathrm{U}$ of Taq DNA polymerase (Eurobio), and $0.1 \mathrm{U}$ of uracyl-N-glycosylase (HK-UNG, Epicentre Technologie, USA) in a final volume of $50 \mu \mathrm{l}$. Each sample was first incubated at $37^{\circ} \mathrm{C}$ for 20 minutes and then denatured at $95^{\circ} \mathrm{C}$ for five minutes. DNA was amplified by 40 successive cycles (20 seconds at $94^{\circ} \mathrm{C}, 40$ seconds at $55^{\circ} \mathrm{C}$, and one minute at $72^{\circ} \mathrm{C}$ ). PCR products were analysed by electrophoresis through a $2 \%$ agarose gel in Tris acetate-EDTA buffer (Sigma, St Quentin Fallavier, France) containing $0.5 \mu \mathrm{g} / \mathrm{ml}$ of ethidium bromide.

PCR-MASA was performed on previously amplified DNA by 40 successive cycles of 30 seconds at $95^{\circ} \mathrm{C}, 50$ seconds at $62^{\circ} \mathrm{C}$, and 50 seconds at $72^{\circ} \mathrm{C}$. The reaction mixture contained $1 \times$ PCR buffer (Eurobio), $2 \mathrm{mM} \mathrm{MgCl}$, $100 \mu \mathrm{M}$ of each deoxyribonucleotide triphosphate (dNTP), $1 \mathrm{U}$ of polymerase enhancer (Perfect Match, Stratagene, Montigny-leBretonneux, France), and 1 U of Taq DNA polymerase (Eurobio) in a final volume of $25 \mu \mathrm{l}$. Codon 12 point mutations of the first or second nucleotide were screened with two different mixtures of primers. Each set contains one common antisense primer and three discriminating sense primers at $0.35 \mu \mathrm{M}$ except for primers exploring the mutations G12C $(\mathrm{GGT} \rightarrow \mathrm{TGT})$ and G12D (GGT $\rightarrow$ GAT) at 0.45 and $0.50 \mu \mathrm{M}$, respectively. PCR-MASA products were subjected to electrophoresis through a $2 \%$ agarose gel containing $0.5 \mu \mathrm{g} / \mathrm{ml}$ of ethidium bromide. When DNA was amplified, giving a band of the expected size, three additional PCR-MASA were performed using the first PCR product as the starting material. Each was carried out with a single set of primers for discriminating each possible point mutation. Final analysis of the PCR-MASA products was carried out by agarose gel electrophoresis, as above.

SEQUENCE SPECIFIC OLIGONUCLEOTIDE

HYBRIDISATION (SSOH)

The first PCR product of each sample was dot blotted onto positive nylon membranes (Appligene, Illkirch, France) and hybridised with radiolabelled oligomer probes. The membranes were prehybridised in $0.05 \mathrm{M}$ phosphate buffer, $\mathrm{pH} 7.0,0.1 \mathrm{M} \mathrm{NaCl}, 0.1 \%$ SDS, and $300 \mu \mathrm{g} / \mathrm{ml}$ of denatured herring sperm DNA for one hour at $54^{\circ} \mathrm{C}$, and then hybridised overnight with ${ }^{32} \mathrm{P}$ labelled oligonucleotide probes recognising either wild-type $\mathrm{Ki}$-ras gene or different Ki-ras mutants. Each olignonucleotide was labelled with $3.7 \times 10^{6} \mathrm{~Bq}$ of $\left[{ }^{32} \mathrm{P}\right]$ labelled $\gamma$ ATP $\left(16.6 \times 10^{13} \mathrm{~Bq} / \mathrm{mmol}\right.$; ICN pharmaceuticals, Orsay, France) and T4 
polynucleotide kinase. Membranes were rinsed at room temperature in $3 \times$ standard saline citrate (SSC) buffer, $0.1 \%$ SDS, and then washed three more times in $3 \times$ SSC for 30 minutes, successively at $58^{\circ} \mathrm{C}, 60^{\circ} \mathrm{C}$, and $62^{\circ} \mathrm{C}$. Autoradiography was performed overnight at $-80^{\circ} \mathrm{C}$ with an intensifying screen. In these conditions, no cross hybridisation was observed between mutated probes.

POSITIVE CONTROL

Six different synthetic DNAs, each with a single point mutation of either the first or second nucleotide of Ki-ras codon 12, were used as positive controls. They were prepared by PCR site directed mutagenesis. Each was included as a positive control in the PCR-MASA and $\mathrm{SSOH}$ analyses.

PRESENTATION OF RESULTS

The frequency of Ki-ras gene point mutations detected in bile specimens was evaluated in different subgroups: malignant strictures (patients from groups 1 and 2 combined) versus benign strictures; primary carcinomas (pancreas, gall bladder, bile duct, or ampulla) versus metastases of other tumours; and primary tumours that developed in the main bile duct (bile duct and ampulla carcinoma) versus tumours possibly invading the bile duct (gall bladder and pancreas carcinomas). Statistical analyses were performed using Fisher's exact test (Statview, Berkeley, California, USA). $\mathrm{p}<0.05$ was considered significant.

\section{Results}

FINAL DIAGNOSIS

Malignant strictures

Imaging data suggested a malignant biliary stricture in 92 of 117 patients, $52(56.5 \%)$ from group 1, 38 (41.3\%) from group 2, and two $(2.1 \%)$ from group 3 . All patients in group 1 had definite cancer, as assessed by histology or cytology on specimens obtained before surgery $(24(46.2 \%))$ and by laparotomy $(28(53.8 \%))$. All patients in group 2 exhibited a progressive alteration of their general status until death, with a median follow up of 4 months (range 1-29 months). The two patients in group 3 (excluded from the analysis) exhibited imaging features in keeping with a malignant stricture. However, one was lost to follow up; the second suffered progressive deterioration of his general status with frequent attacks of cholangitis but was still alive after a follow up period of 18 months.

Table 1 Sensitivity, specificity, and positive and negative predictive values of Ki-ras point mutation detected in bile specimens and non-surgical histological results (histology) in the diagnosis of malignant versus benign biliary strictures

\begin{tabular}{llccl}
\hline & Sensitivity (\%) & Specificity (\%) & PPV (\%) & NPV (\%) \\
\hline SSOH & 17 & 96 & 94 & 15 \\
PCR-MASA & 24 & 96 & 95 & 23 \\
SSOH and PCR-MASA & 25 & 96 & 96 & 25 \\
Histology & 59 & 100 & 100 & ND \\
Histology and Ki-ras mutations & 73 & 96 & 97 & ND \\
\hline
\end{tabular}

PPV, positive predictive value; NPV, negative predictive value; ND, not done.

$\mathrm{SSOH}$, sequence specific oligonucleotide hybridisation; PCR-MASA, polymerase chain reactionmutant allele specific amplification.
Benign strictures

The biliary stricture was considered benign in 25 of 117 patients. The final diagnosis was: chronic pancreatitis in six, bile duct lithiasis in eight, post-surgical stricture in four, sclerosing cholangitis in five, portal cavernoma in one, and papillary sclerosis in one. All patients in this group remained alive with a stable general status. Median follow up was 18 months (range 12-49 months).

AMPLIFICATION OF DNA FROM BILE SPECIMENS Amplification of the 286 bp of Ki-ras DNA was successful in 110 of 117 bile samples (94\%). The wild-type sequence was detected in all 110 cases by both SSOH and PCR-MASA. To determine the cause of the failure of DNA amplification in the remaining seven bile specimens (obtained from patients with one benign and six malignant strictures, respectively), control DNA extracted from HeLa cells was added to these samples before the first PCR. This control DNA could not be amplified, suggesting that inhibitors of PCR were present in these seven bile specimens, as already suggested for stools. ${ }^{19}$

POINT MUTATIONS OF Ki-ras IN DNA AMPLIFIED FROM BILE SPECIMENS

Table 1 shows the sensitivity, specificity, and positive and negative predictive values of $\mathrm{Ki}$-ras point mutations detected in bile specimens for confirmation of malignant strictures. Figure 1 shows the 22 point mutations detected in bile specimens sampled from the 90 patients in groups 1 and $2(24.4 \%$ sensitivity, $95 \%$ confidence interval $15.5-33.3 \%)$. Ki-ras point mutations were detected in $31.4 \%(22 / 70)$ of cases of primary tumours compared with $0 / 20$ metastases of other tumours $(\mathrm{p}<0.05)$, and in $27.3 \%(9 / 33)$ of tumours developed in the main bile duct (bile duct and ampulla carcinomas) versus $35.1 \%(13 / 37)$ of cases of gall bladder or pancreas carcinomas (NS). One mutation was detected in the 25 bile specimens originating from patients with benign strictures (96.0\% specificity, 95\% confidence interval $88.3-100.0 \%)$. The patient had a jejuno-biliary anastomosis previously performed for complicated cholecystectomy. He was followed for 36 months after bile drainage and did not exhibit

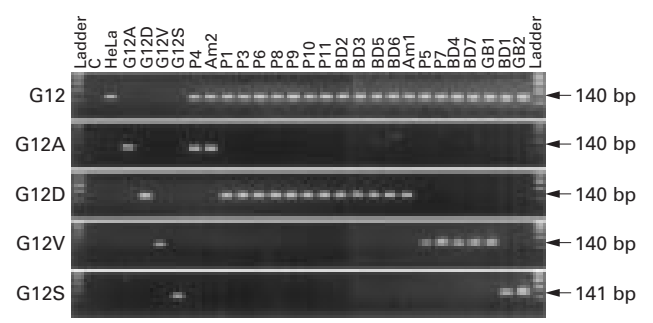

Figure 1 Gel electrophoresis analysis of the PCR-MASA products stained by ethidium bromide. Wild-type (G12) as well as mutated amplified DNA fragments are specified to the left. The origin of the amplified sample is indicated above (C, control without DNA; HeLa, HeLa cell DNA; G12A, G12D, G12V, and G12S, positive control DNA in which GGT codon 12 was changed for GCT, GAT, GTT, and AGT respectively; wild-type and mutated DNA originating from bile specimens of patients exhibiting pancreas (P), ampulla (Am), bile duct (BD), and gall bladder $(G B)$ cancer. 
any change in his general well being. He was therefore considered as having a benign biliary stricture. The predictive positive and negative values of Ki-ras mutation analysis for differentiating between benign and malignant biliary strictures were $96 \%$ and $25 \%$, respectively.

PATIENTS WITH HISTOLOGICAL SPECIMENS

OBTAINED BEFORE SURGERY

The diagnosis of malignant biliary strictures by non-surgical methods rests on examination of biopsies or cells obtained by endoscopy or percutaneous fine needle aspiration. ${ }^{6}{ }^{20}$ However, such analyses are not $100 \%$ reliable and give negative results even in cases of definite malignant strictures, as demonstrated later by surgical means. ${ }^{6}$ The prevalence of Ki-ras point mutations was thus assessed in bile specimens from 49 patients with malignant strictures (groups 1 and 2) and with histological specimens obtained before surgery (endoscopic brushing in 16, endoscopic biopsies in 14 , percutaneous cytology in 19). These histological specimens showed criteria for malignancy in $29(59.2 \%)$ of the 49 cases. Ki-ras mutations were detected in bile specimens from $14(28.6 \%)$ of these 49 cases, including seven of the $20(35.0 \%)$ cases for whom the histological specimen was negative. In this group of 49 patients, the sensitivity of histology, Ki-ras mutation analysis, and combined methods were $59.2 \%, 28.7 \%$, and $73.5 \%$, respectively (table 1 ). The predictive negative value of histology and combined methods is not stated because histological specimens were available in only two patients with benign strictures.

COMPARISON BETWEEN SSOH AND PCR-MASA Two G12A, 12 G12D, five G12V, and two G12S mutations were identified after PCRMASA in bile samples from patients with malignant strictures. Concordance with the results given by the two methods was complete in all 15 cases that harboured a $\mathrm{Ki}$-ras point mutation simultaneously detected by both methods. In seven cases, SSOH was not sensitive enough for detecting the point mutation found by PCR-MASA, irrespective of the nature of the mutation. One mutation identified by SSOH could not be screened by PCRMASA (the sample was lost).

\section{Discussion}

The present study is the first large prospective series reporting the diagnostic power of $\mathrm{Ki}$-ras mutation analysis in bile samples from patients with malignant and benign biliary strictures. DNA was extracted from bile specimens and amplified successfully by PCR in $94 \%$ of the 117 cases. Ki-ras gene point mutations of codon 12 were detected in one third of bile specimens from patients with primary tumours but in none of 20 bile specimens from patients with liver metastases. Moreover, in patients with histological specimens obtained before surgery, detection of $\mathrm{Ki}$-ras mutations in bile specimens improved the diagnosis of malignancy over histology alone.
Detecting Ki-ras point mutations in bile samples relies primarily on the success of the first DNA amplification by PCR, which failed in up to $45 \%$ of cases in preliminary studies. ${ }^{17} 18$ In our series, amplification was unsuccessful in only $6 \%$ of cases, probably not because of the absence of DNA in the sample but of the likely presence of DNA polymerase inhibitors that could not be eliminated from the bile specimens. When DNA amplification was successful, there was perfect concordance between SSOH and PCR-MASA regarding the type of Ki-ras mutation, but PCR-MASA was clearly more sensitive than $\mathrm{SSOH}$. Interestingly, this method has no major technical difficulties and is fast enough to give results within 48 hours. Systematic use of dUTP instead of dTTP, together with treatment with uracyl $\mathrm{N}$-glycosylase before the first PCR, eliminated false positives due to possible contamination by products of previous amplifications. Therefore, each point mutation depicted in our study was considered as existing in the original DNA sample.

Because of its high specificity, detection of tumour DNA in biological samples, in common with Ki-ras gene mutations in the present series, may represent an important tool for the diagnosis of malignancy in the future. The sensitivity of Ki-ras mutation analysis is however limited by the prevalence of these mutations in the tumour type under investigation, and is dependent on the presence of a sufficient amount of tumour cells in the biological sample used for the analysis. The prevalence of Ki-ras mutations, as assessed directly from tumour samples, was shown to be high in pancreatic and biliary tumours: $80-95 \%$ for pancreatic adenocarcinomas, $50-100 \%$ for cholangiocarcinomas, and $39-55 \%$ for gall bladder adenocarcinomas. ${ }^{1321-23}$ In cases of malignant biliary strictures, negative results obtained from Ki-ras mutation analysis of bile specimens may be explained in several ways. Firstly, as stated before, the tumour itself may present no Ki-ras mutation. Secondly, the tumour may reject a low amount of malignant cells in bile because of its scirrhous nature (for example, most cholangiocarcinomas) or because of extraluminal development (for example, some cancers of the pancreas). In particular, no mutations were detected in liver metastases from distant tumours, as previously reported, ${ }^{18}$ which suggests that metastases compress rather than invade the main bile duct and do not reject a sufficient amount of malignant cells in bile. Several methods could be used to improve the detection of tumour DNA when drainage of potentially malignant bile duct strictures is scheduled. These are detection of different (codon 13 and codon 61) point mutations of the Ki-ras gene, search for DNA abnormalities different from Ki-ras mutations in bile specimens, and finally DNA amplification on samples obtained by brushing of the stricture itself instead of bile specimens. ${ }^{13}$ 22-24

This work was supported by grants from Centre National de la Recherche Scientifique, Fondation de France, and Hospices civils de Lyon. 
1 Choi BI, Lee JH, Han MC, et al. Hilar cholangiocarcinoma: comparative study with sonography and CT. Radiology comparative study

2 Foutch PG. Diagnosis of cancer by cytologic methods performed during ERCP. Gastrointest Endosc 1994;40:24952.

3 Foutch PG, Kerr DM, Harlan JR, et al. A prospective, controlled analysis of endoscopic cytotechniques for diagnosis of malignant biliary strictures. Am F Gastroenterol 1991;86 577-80.

4 Savader SJ, Prescott CA, Lund GB, et al. Intraductal biliary biopsy: comparison of three techniques. $\mathcal{F}$ Vasc Interv Radiol 1996;7:743-50.

5 Rustgi AK, Kelsey PB, Guelrud M, et al. Malignant tumors of the bile ducts: diagnosis by biopsy during endoscopic cannulation. Gastrointest Endosc 1989;35:248-51.

6 Ponchon T, Gagnon P, Berger F, et al. Value of endobiliary brush cytology and biopsies for the diagnosis of malignant bile duct stenosis: results of a prospective study. Gastrointest Endosc 1995;42:565-72.

Endosc 1995; 42:565-72.
7 Kurzawinski TR, Deery A, Dooley JS, et al. A prospective Kurzawinski TR, Deery A, Dooley JS, et al. A prospective
study of biliary cytology in 100 patients with bile duct study of biliary cytology in 100 patien
strictures. Hepatology 1993;18:1399-403.

strictures. Hepatology 1993;18:1399-403.
8 Howell DA, Parsons WG, Jones MA, et al. Complete tissue sampling of biliary strictures at ERCP using a new device. Gastrointest Endosc 1996;43:498-502.

9 Lurie BB, Loewenstein MS, Zamcheck N. Elevated carcinoembryonic antigen levels and biliary tract obstruction. $7 A M A$ 1975;233:326-30.

10 Pearce S, Thornes H, Carr D, et al. Diagnostic pitfall interpretation of CA 19-9 concentrations in the presence of hepatic dysfunction. Gut 1994;35:707-8.

11 Laurent-Puig P, Lubin R, Semhoun-Ducloux S, et al. Antibodies against $\mathrm{p} 53$ protein in serum of patients with benign or malignant pancreatic and biliary diseases. Gut 1995:36. 455-8.

12 Sears RI, Duckworth CW, Decaestecker C, et al. Image cytometry as a discriminatory tool for cytologic specimens cytometry as a discriminatory tool for cytologic specimens phy. Cancer 1998;84:119-26.

phy. Cancer 1998;84:119-26.
13 Watanabe M, Asaka M, Tanaka J, et al. Point mutation of K-ras gene codon 12 in biliary tract tumors. Gastroenterology 1994;107:1147-53.
14 Hruban RH, Sturm PD, Slebos RJ, et al. Can K-ras codon 12 mutations be used to distinguish benign bile duct proliferations from metastases in the liver? A molecular analysis of 101 liver lesions from 93 patients. Am F Pathol 1997;151: 943-9.

15 Bos JL. Ras oncogenes in human cancer: a review. Cancer Res 1989;49:4682-9.

16 Villanueva A, Reyes G, Cuatrecasas M, et al. Diagnostic utility of K-ras mutations in fine-needle aspirates of pancreatic masses. Gastroenterology 1996;110:1587-94.

17 Ajiki T, Onoyama H, Yamamoto M, et al. Detection of point mutations in K-ras gene at codon 12 in bile from percutaneous transhepatic choledochal drainage tubes for diagnosis of biliary strictures. Int F Pancreatol 1995;18:215-20.

18 Lee JG, Leung JW, Cotton PB, et al. Diagnostic utility of K-ras mutational analysis on bile obtained by endoscopic retrograde cholangiopancreatography. Gastrointest Endosc 1995;42:317-20.

19 Hasegawa Y, Takeda S, Ichii S, et al. Detection of K-ras mutations in DNAs isolated from feces of patients with colorectal tumors by mutant-allele-specific amplification (MASA). Oncogene 1995;10:1441-5.

20 Desa LA, Akosa AB, Lazzara S, et al. Cytodiagnosis in the management of extrahepatic biliary stricture. Gut 1991;32: 1188-91.

21 Tada $M$, Omata $M$, Ohto $M$. High incidence of ras gene mutation in intrahepatic cholangiocarcinoma. Cancer 1992;69:1115-8.

22 Levi S, Urbano-Ispizua A, Gill R, et al. Multiple K-ras codon 12 mutations in cholangiocarcinomas demonstrated with a sensitive polymerase chain reaction technique. Cancer Res 1991;51:3497-502.

23 Imai M, Hoshi T, Ogawa K. K-ras codon 12 mutations in biliary tract tumors detected by polymerase chain reaction denaturing gradient gel electrophoresis. Cancer 1994;73: 2727-33.

24 Van Laethem JL, Bourgeois V, Parma J, et al. Relative contribution of Ki-ras gene analysis and brush cytology during ERCP for the diagnosis of biliary and pancreatic diseases. Gastrointest Endosc 1998;47:479-85. 